\title{
A new species of Monoscutidae (Arachnida, Opiliones) from the wheatbelt of Western Australia
}

\author{
Christopher Taylor \\ Department of Envirommental Biology, Curtin University of Fechnology, GPO Box U1987, Perth, \\ Western Australia 6845, Australia. E-mail: c.taylor1@student.curtin.eduau
}

\begin{abstract}
Megalopsalis limaci sp. nov. is described from the Wheatbelt region of Western Australia. Though most similar to species of Monoscutidae (Opiliones) previously assigned to the Megalopsalidinae, M. linmat lacks the significant sexual dimorphism previously regarded as characteristic of the subfamily.
\end{abstract}

\section{INTRODUCTION}

The family Monoscutidae Forster 1948 (Arachnida, Opiliones) is widespread in New Zealand and southern and eastern Australia (Forster 1949; Taylor 2004). The New Zealand fauna has been further investigated taxonomically (Forster 1944, 1948, 1964; Taylor 2004) than the Australian fauna (Forster 1949; Hickman 1957), and about two-thirds of the currently recognised species of Monoscutidae are from New Zealand (Taylor 2004). The presence of long-legged harvestmen in Western Australia was first recorded by Forster (1950), but he was unable to identify any species due to only having juvenile specimens on hand. Kauri (1954) described two species from the Porongorups region of Western Australia, Spinicrus minimum Kauri 1954 and $S$. porongorupense Kauri 1954.

The two subfamilies of Monoscutidae currently recognised, Monoscutinae Forster 1948 and Megalopsalidinae Forster 1949, were both originally described as separate subfamilies in the Phalangiidae. They were united as the subfamily Megalopsalinae [sic] in the Neopilionidae by Silhavy (1970), before being raised to family level as Megalopsalididae by Martens (1976). The Monoscutinae have been characterised by being heavily sclerotised and lacking significant sexual dimorphism (Forster 1948). The Megalopsalidinae, in contrast, are not as heavily sclerotised and exhibit significant sexual dimorphism, with the male more sclerotised and the male chelicerae enlarged, sometimes considerably longer than the body (Taylor 2004). The recent discovery of a sclerotised species of Monoscutidae with enlarged chelicerae in the male (Taylor 2008) was the first threat to the integrity of these two previously quite distinct subfamilies. The description here of a new non-sclerotised species most similar to other species placed in Megalopsalidinae, but lacking significant sexual dimorphism, further highlights the need for a reassessment of divisions within the Monoscutidae.

\section{METHODS}

Specimens were sourced from the collection of the Western Australian Museum (WAM), examined under $70 \%$ ethanol using a Leica MZ6 stereo microscope and drawn with the aid of a camera lucida. Colours are described in alcohol. Measurements were taken of the holotype and paratypes (18 males and 8 females) using a graticule. Where not all specimens in a paratype vial were measured, the number measured is indicated. Other specimens listed below were not measured. Measurements are given as means in millimetres, with standard deviations in parentheses. Genitalia were removed using a pair of forceps and examined under an Olympus BH-2 compound microscope mounted in $\mathrm{K}-\mathrm{Y}$ brand jelly as described in Cokendolpher and Sissom (2000). Genitalia and pedipalp specimens were examined using SEM microscopy after drying in sequential washes of increasing concentrations of ethanol to $100 \%$, followed by washing in hexamethyl-disilazane (HMDS) and air-drying as described by Nation (1983).

\section{SYSTEMATICS}

\section{Family Monoscutidae Forster 1948}

\section{Megalopsalis Roewer 1923}

Macropsalis Sorensen 1886: 54 (junior homonym of Maropsalis Sclater 1866).

Megalopsalis Roewer 1923: 866 (replacement name for Macropsalis Sorensen 1886).

\section{Type species}

Macropsalis serritarsus Sorensen 1886 , by monotypy. 


\section{Diagnosis}

Male prosoma not significantly sclerotised Patella of pedipalp with large rounded apophysis present in both sexes, densely covered in plumose setae.

\section{Remarks}

Megalopsalis serritarsus has not been redescribed since its original publication, and a wide variety of species have since been assigned to Megalopsalis that do not particularly resemble the type species (Forster 1944). The diagnosis above is based on Sørensen's (1886) original description and observations of comparable specimens from the collection of the Australian Museum (AMS), and is provisional only. Most significantly, the genitalia of Megalopsalis serritarsus remain undescribed. Many of the New Zealand species assigned to Megalopsalis do not comply with this diagnosis, having small triangular pedipalp apophyses without a dense covering of setae (Taylor 2004), and probably represent a different taxon.

\section{Megalopsalis linnaei sp. nov.}

Figures 1-14

\section{Material examined}

\section{Holotype}

Australia: Western Australia: $\delta$, Lake Gounter Nature Reserve (site KN 13), 32 $23^{\prime} 48^{\prime \prime} \mathrm{S} 118^{\circ} 49^{\prime} 06^{\prime \prime} \mathrm{E}$, 19 May - 22 Sept. 1998, wet pitfalls, P. Van Heurck, CALM Survey (WAM T72981).

\section{Paratypes}

Australia: Western Australia: 2 o, 3 \%, Bruce Rock-Doodlakine Road, 31 51'26"S 118 06'14"E, 22 May - 22 Sept. 1998, wet pitfalls, N. Guthrie, CALM Survey (WAM T73006; $2 \delta$ and $1 q$ measured); 1 3, Comitun Dam Nature Reserve, $31^{\circ} 45^{\prime} 38^{\prime \prime S} 118^{\circ} 03^{\prime} 47^{\prime \prime E}, 22$ May - 29 Sept. 1998, wet pitfalls, L. King, CALM Survey (WAM T73034); 1

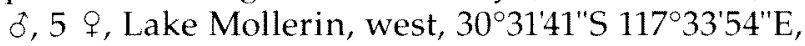
15 Sept. 1998 - 25 Oct. 1999, wet pitfalls, P. Van Heurck, CALM Survey (WAM T73036; $1 q$ measured); 19 d, $12 \%$, Long Muir Rd, granite rock, S of Mollerin Lake, 30 $32^{\prime} 50^{\prime \prime} \mathrm{S} 117^{\circ} 33^{\prime} 56^{\prime \prime} \mathrm{E}$, 16 Sept. 1998 - 25 Oct. 1999, wet pitfalls, P. Van Heurck, CALM Survey (WAM T73000; $6 \delta$ and $7 q$ measured); 11 ठ, 7 \%, Mungarri Nature Reserve, north, 30 $19^{\prime} 51^{\prime \prime} \mathrm{S} 117^{\circ} 45^{\prime} 12^{\prime \prime} \mathrm{E}, 15$ Sept. 1998 - 25 Oct. 1999, wet pitfalls, P. Van Heurck, CALM Survey (WAM T73041; 3 o measured); 4 o, 1 \% Noorajin Soak Nature Reserve, $30^{\circ} 45^{\prime} 17^{\prime \prime} \mathrm{S}$ $117^{\circ} 14^{\prime} 30^{\prime \prime E}, 15$ Sept. 1998 - 18 Oct. 1999, N. A. Guthrie, CALM Survey (WAM T73060; 2 ठ measured); 1 , Pinjarrega Nature Reserve, 3003'42"S 115 55'17'E, 15 Oct. 1999 - 1 Nov. 2000, wet pitfalls, $P$. Van Heurck et al., CALM Survey
(WAM T73082); 8 ¿, 3 \&, Vermin Proof Fence, east, E of Beacon, $30^{\circ} 14^{\prime} 17^{\prime \prime} S 118^{\circ} 20^{\prime} 09^{\prime \prime} \mathrm{E}, 15$ Sept. 1998 - 25 Oct. 1999, wet pitfalls, P. Van Heurck, CALM Survey (WAM T73002; 2 measured).

\section{Other specimens examined}

Australia: Western Australia: 1 q, Badjaling Siding, 31 59'10"S 117 $29^{\prime} 53^{\prime \prime} \mathrm{E}, 27$ May - 5 Oct. 1998, wet pitfalls, $P$. Van Heurck, CALM Survey (WAM T73008); 3 d, 2 \&, Bendering Reserve Road, 32 21'27"S 118 29'46"E, 19 May - 22 Sept. 1998, wet pitfalls, N. Guthrie, CALM Survey; 1

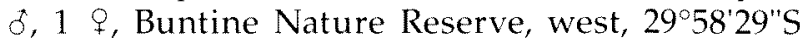
116 34'59"E, 15 Sept. 1998 - 25 Oct. 1999, wet pitfalls, L. King, CALM Survey (WAM T72990); 1 , Dragon Rocks Nature Reserve, northern end, $32^{\circ} 41^{\prime} 27^{\prime \prime} \mathrm{S} 118^{\circ} 58^{\prime} 30^{\prime \prime E}, 20$ May - 22 Sept. 1998, wet pitfalls, N. A. Guthrie, CALM Survey (WAM T73019); 1 \&, Durokoppin Nature Reserve, south, $31^{\circ} 24^{\prime} 46^{\prime \prime} \mathrm{S} 117^{\circ} 45^{\prime} 16^{\prime \prime} \mathrm{E}, 22 \mathrm{May}-22$ Sept. 1998, wet pitfalls, L. King, CALM Survey (WAM T72983); 79 , Erikin Road, W of Bruce Rock, 31 $57^{\circ} 51^{\prime \prime} \mathrm{S}$ $117^{\circ} 56^{\prime} 05^{\prime \prime E}, 22$ May - 29 Sept. 1998, wet pitfalls, L. King, CALM Survey (WAM T72957); 2 ơ, Koorda Rd, Nature Reserve 22363, 30 45'25'S $117^{\circ} 05^{\prime} 26^{\prime \prime} \mathrm{E}$, 15 Sept. 1998 - 25 Oct. 1999, wet pitfalls, B. Durrant, CALM Survey (WAM T73012); 1 \%, Kulja-Mollerin Rock Road, 30'31'50'S 117 3349"E, 15 Sept. 1998 - 25 Oct. 1999, L. King, CALM Survey (WAM T73046); 1 oे, Lochada Road Nature Reserve, south-east, $2^{\circ} 15^{\prime} 34^{\prime \prime} S 116^{\circ} 23^{\prime} 08^{\prime \prime} \mathrm{E}, 15$ Sept. 1998 - 18 Oct. 1999, wet pitfalls, L. King, CALM Survey (WAM T73011); 1 \%, Mt Hampton Nature Reserve, dam, 31 4540"S 11904'21"E, 29 April 22 Sept. 1998, wet pitfalls, N. A. Guthrie, CALM Survey (WAM T73003); 1 \&, Mt Hampton Nature Reserve, north, 31 44'26"S 119 05'02"E, 29 April - 22 Sept. 1998, P. Van Heurck, CALM Survey (WAM T73017); 4 \&, Mt Moore Nature Reserve, 31 12'45"S 118 18'15"E, 21 May - 22 Sept. 1998, wet pitfalls, N. A. Guthrie, CALM Survey (WAM T73007); 1 o, 1 \&, Mungarri Nature Reserve, south, 30'20'55"S $117^{\circ} 45^{\prime} 29^{\prime \prime} \mathrm{E}, 15$ Sept. 1998 - 25 Oct. 1999, wet pitfalls, L. King, CALM Survey (WAM T73091); 1 ?, Talgomine Reserve, north, $\mathrm{N}$ of Merredin, 31 $14^{\prime} 40^{\prime \prime S} 118^{\circ} 24^{\prime} 25^{\prime \prime}$ E, 28 April - 22 Sept. 1998, wet pitfalls, N. A. Guthrie, CALM Survey (WAM T73009); 1 o. Tambellup water supply reserve, $34^{\circ} 02^{\prime} 20^{\prime \prime S} 117^{\circ} 33^{\prime} 30^{\prime \prime}$ E, 15 Oct. 1999 - 1 Nov. 2000, $P$. Van Heurck et al., CALM Survey (WAM T73088); 2 \&. Wamenusking Nature Reserve, 32 $07^{\prime} 34^{\prime \prime S}$ 117 30'31'E, 26 May - 5 Oct. 1998, wet pitfalls, N. A. Guthrie, CALM Survey (WAM T72968); 1 क, Yarding Nature Reserve, 31 55'02"S 117 58'49"E, 22 May - 29 Sept. 1998, wet pitfalls, L. King, CALM Survey (WAM T72979).

\section{Diagnosis}

Megalopsalis linnaei differs from all other 


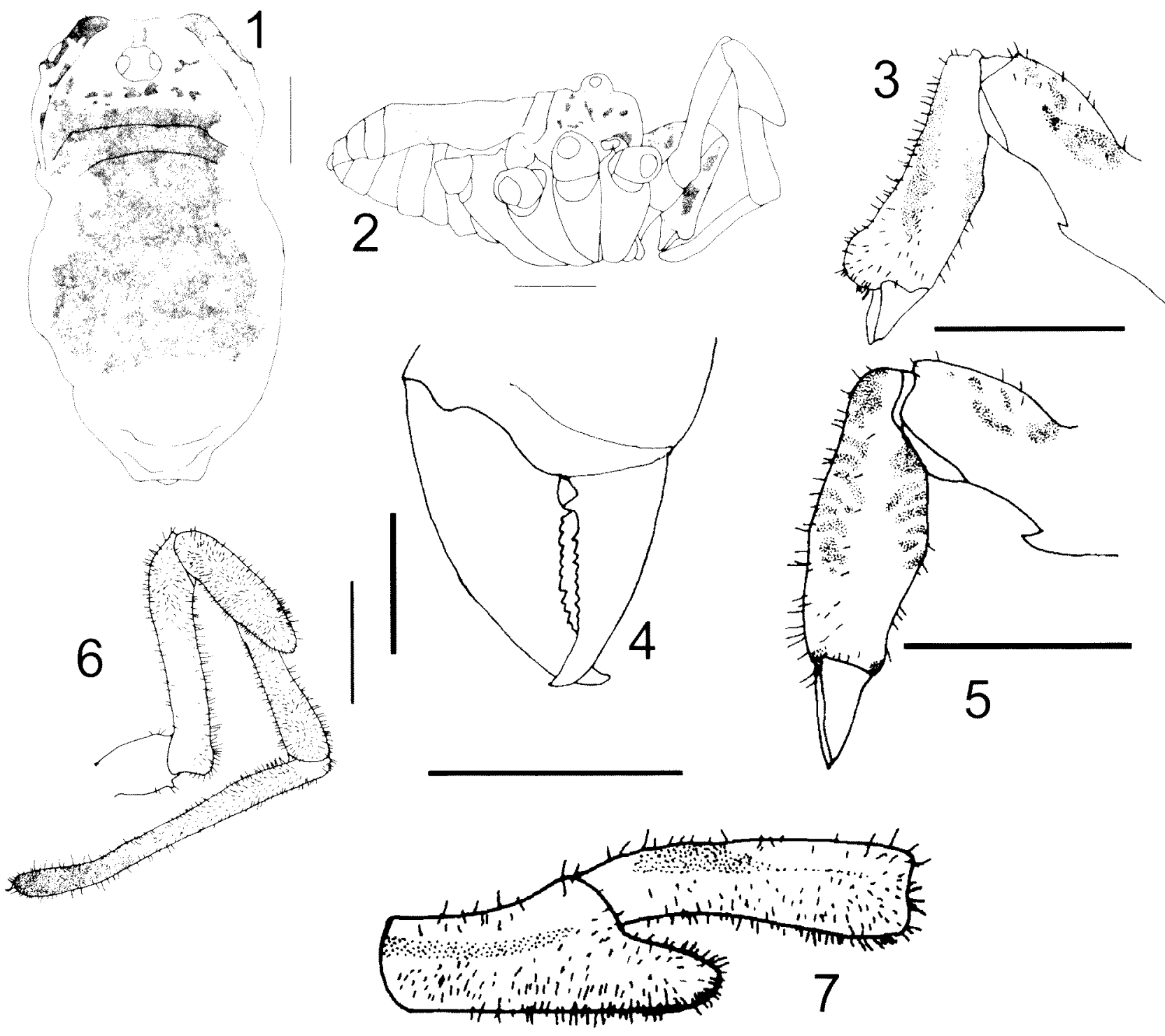

Figures 1-7 Megalopalis limari, new species: 1, dorsal view, female (WAM T73000); 2, lateral view, male holotype (setae omitted); 3, left male chelicera, lateral view (WAM T73000); 4, right male chelicera, frontal view (WAM T73000); 5, left female chelicera, hateral view (WAM T73000); 6, left female pedipalp, medial view (WAM T73000); 7, left female pedipalp, dorsal view (WAM T73000). Scale bars $=1 \mathrm{~mm}$ (Figure 1-3), $0.2 \mathrm{~mm}$ (Figure $4)$.

Monoscutidae in its lack of both heavy sclerotisation and enlarged chelicerae in the male. The male is also distinguished from all other monoscutid species by its frontal cheliceral apophysis. The female is distinguished from all other Monoscutidae by the round opening at the anterior of the genital operculum.

\section{Description}

Male

Prosoma length 1.24 (0.12), width $2.15(0.16)$. Carapace white with brown ticking and scattered darker brown patches; smooth. Ocularium white with brown ticking, unarmed. Ozopore large, easily visible from above, with flanking lobes. Bright white lateral areas on prosoma and dorsum of first two opisthosomal segments. Medial zone of first two segments, and all of third and fourth segments of dorsum of opisthosoma dark brown. Posterior of opisthosoma white ticked with brown medially and bright white laterally. Spiracle with branched covering spines arising from anterior margin. Genital operculum without circular opening on anterior margin. Interior of genital operculum with sclerotised recess for penis. Choldina: Segment I $0.83(0.10)$, segment II $1.56(0.09)$. White with brown patches; unarmed; large frontal apophysis on anteriodistal face of segment II (Figure 3). Outer edge of fingers 

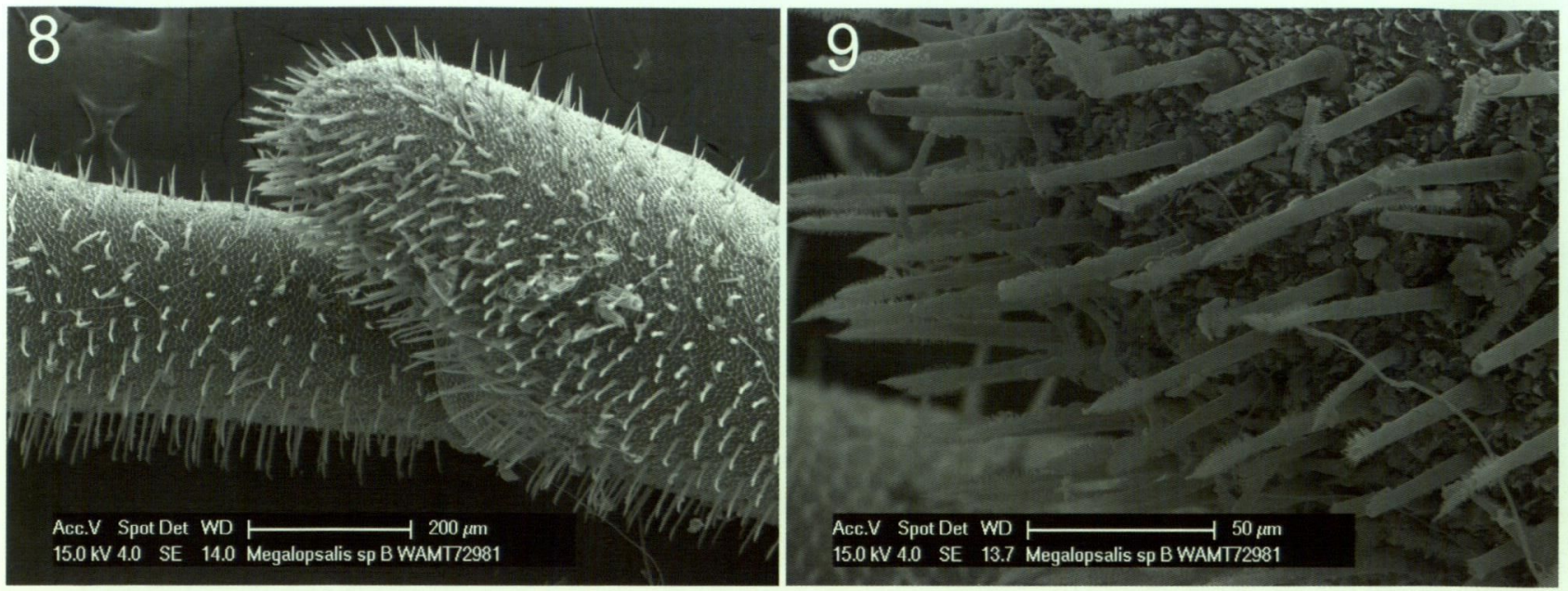

Figures 8-9 Megalopsalis linnaei, new species: 8, right male pedipalp, medial view of patellar apophysis, showing laterodorsal non-plumose and medioventral plumose setae (WAM T73000); 9, same, close-up of plumose setae.

smoothly convex (Figure 4). Pedipalps: Femur 1.77 (0.10), patella $0.92(0.06)$, tibia $1.17(0.05)$, tarsus $2.04(0.12)$. Femur, patella and tibia white with tan patches; tarsus tan. All segments unarmed. Femur to tibia with dense plumose setae medially, fewer non-plumose setae laterally (Figures 8-9). Tarsus with plumose setae over proximal two-thirds, non-plumose setae and aciculate ornamentation over distal third. Large rounded distal apophysis on patella and distal medial bulge on femur and tibia (see Figures 6-7). Tarsal claw without ventral teeth. Legs: Femora 2.95 (0.23), 5.90 (0.39), 2.97 (0.29), $4.44(0.22)$; patellae $1.12(0.08), 1.46(0.11), 0.99$ (0.05), 1.01 (0.07); tibiae 2.77 (0.25), 5.32 (0.38), 2.45
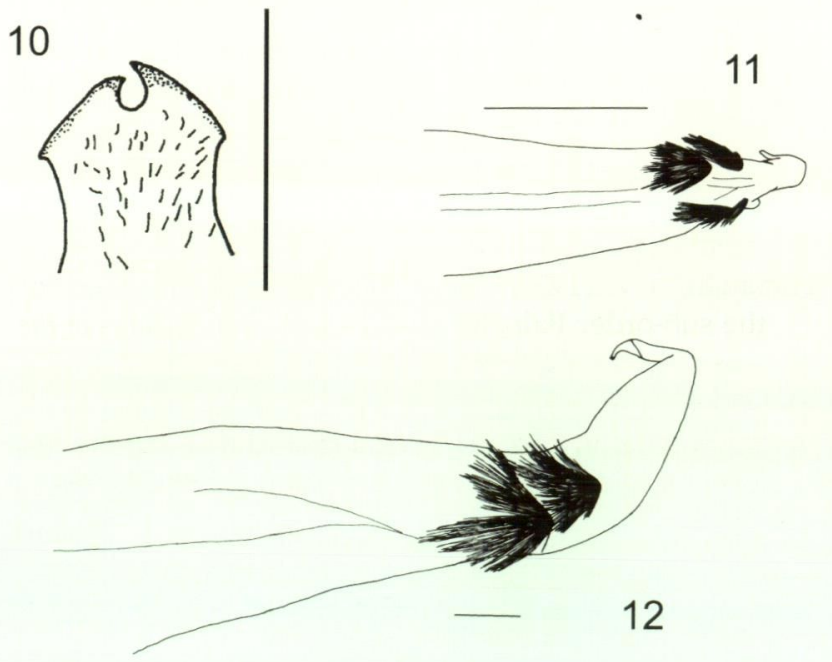

Figures 10-12 Megalopsalis linnaei, new species: 10, anterior portion of female genital operculum (WAM T73000); 11, penis, ventral view (holotype); 12, penis, right lateral view (holotype). Scale bars $=1 \mathrm{~mm}$ (Figure 10), except $0.05 \mathrm{~mm}$ (Figure 11), $0.01 \mathrm{~mm}$ (Figure 12).
(0.20), 3.18 (0.15). Femora unarmed; femora and patellae with longitudinal rows of setae. Tibiae with longitudinal rows of setae and densely covered with aciculate ornamentation. Tibia I with increased density of setae ventrally. Tibiae not pseudosegmented. Penis: (Figures 11-14) Heavily sclerotised; shaft flattened dorsoventrally. Glans at $\sim 90^{\circ}$ from shaft; all four bristle groups welldeveloped, with right bristle groups significantly larger than left-hand groups. Left side of glansshaft junction with plate-like dorsolateral process (Figure 13). Glans laterally compressed, subrectangular in left lateral view to triangular in right lateral view, torted anti-clockwise in distal view. Pores on glans on raised papillae (Figure 14). Stylus attached at right distal end of glans, strongly recurved back onto glans.

Female: (Figure 1) Prosoma length 1.33 (0.17), width 2.40 (0.15). As for male except for following: Genital operculum with circular medial opening on anterior margin (Figure 10). Chelicerae: (Figure 5) Segment I 0.72 (0.07), segment II 1.62 (0.06). No frontal apophysis on second segment (Figure 5). Pedipalps: Femur 1.71 (0.07), patella 0.89 (0.09), 1.26 (0.06), tarsus 2.29 (0.12). Legs: Femora 2.06 (0.10), $4.08(0.18), 1.91(0.10), 3.12(0.16) ;$ patellae 0.96 $(0.08), 1.31(0.06), 0.90(0.05), 0.99(0.03)$; tibiae 2.12 (0.12), 4.15 (0.10), $1.84(0.10), 2.44(0.09)$.

\section{Remarks}

Despite its distinctiveness from other Monoscutidae, most of the notable features of Megalopsalis linnaei are unique to this species, and so uninformative about its relationships. It is similar to Monoscutinae in having small male chelicerae and relatively short legs (Forster, 1948). However, the absence of significant sclerotisation, the distinct separation dorsally of the prosoma from the opisthosoma, and the 

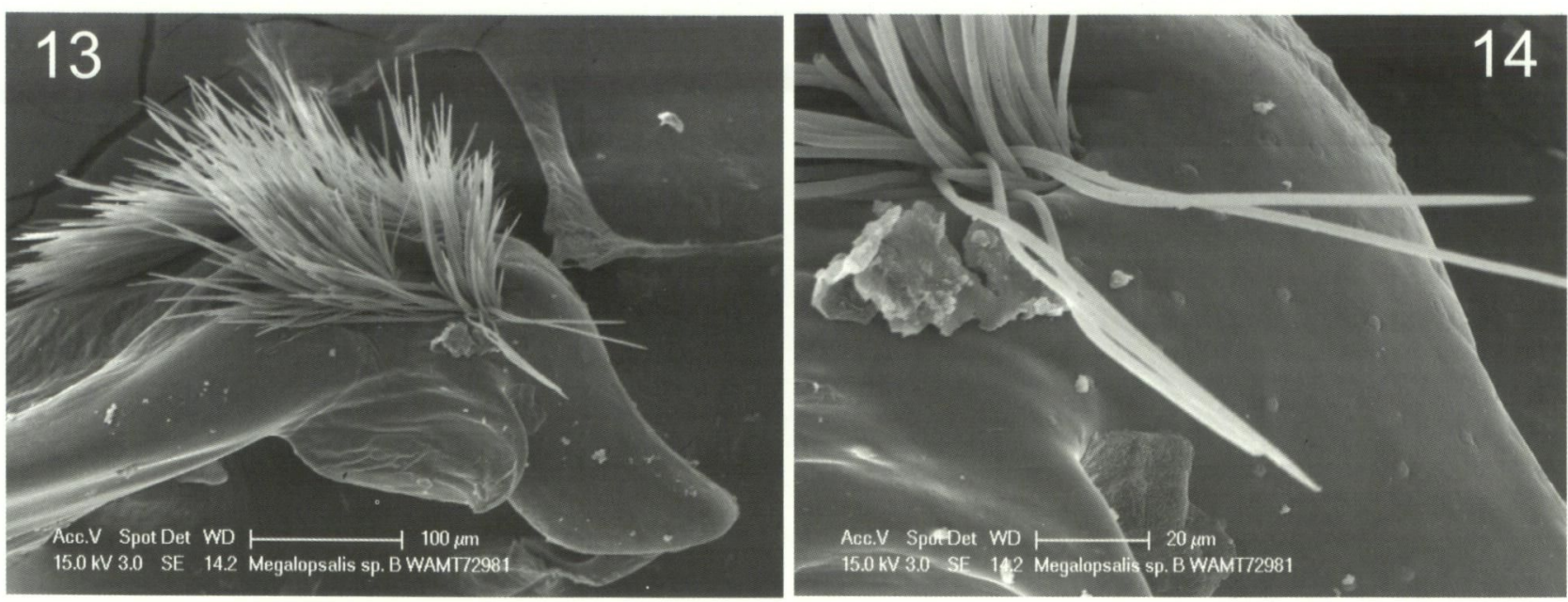

Figures 13-14 Megalopsalis linnaei, new species: 13, glans, left lateral view (holotype); 14, same, close-up showing raised pores.

large ozopore easily visible from above with distinct flanking lobes are more characteristic of the Megalopsalidinae. The spiracle of the current species is comparable to those illustrated by Hunt (1990) for Western Australian species of Megalopsalis, while the spiracle of an undescribed Australian species of Monoscutinae was illustrated by Hunt (1990) with spines on the posterior margin. The genera of Megalopsalidinae are mostly poorly defined, and might be expected to change in composition in the future (Taylor, 2004). Due to the similarity of the pedipalp of the new species to that of Megalopsalis serritarsus, it is provisionally included in Megalopsalis pending a more thorough analysis of its relationships.

\section{Etymology}

Named after Carl Linnaeus to commemorate the $250^{\text {th }}$ anniversary of the publication of the $10^{\text {th }}$ edition of Systema Naturae (Linnaeus, 1758), regarded as the initial publication for binomial nomenclature in animals (International Commission on Zoological Nomenclature 1999).

\section{ACKNOWLEDGEMENTS}

I would like to thank Julianne Waldock and Mark Harvey at the Western Australian Museum for arranging the loan of the specimens used in this report, and for advice on their study. Thanks are also due to Elaine Miller at Curtin University of Technology for her training on the use of the Scanning Electron Microscope, and James Arnold of the West Virginia Arachnid Survey for informing me of the drying method used to prepare the specimens used in electron microscopy. Work was conducted at Curtin University of Technology in Perth.

\section{REFERENCES}

Cokendolpher, J.C., and Sissom, W.D. (2000). Further contributions to the study of Dalquestia (Opiliones, Sclerosomatidae). Entomological News 111: 243-249.

Crawford, R.L. (1992). Catalogue of the genera and type species of the harvestman superfamily Phalangioidea (Arachnida). Burke Museum Contributions in Anthropology and Natural History 8: 1-60.

Forster, R.R. (1944). The genus Megalopsalis Roewer in New Zealand with keys to the New Zealand genera of Opiliones. Records of the Dominion Museum 1: 183-192.

Forster, R.R. (1948). A new sub-family and species of New Zealand Opiliones. Records of the Auckland Institute and Museum 3: 313-318.

Forster, R.R. (1949). Australian Opiliones. Memoirs of the National Museum of Victoria 16: 59-89.

Forster, R.R. (1950). Western Australian Opiliones. Journal of the Royal Society of Western Australia 36: 23-29.

Forster, R.R. (1964). The Araneae and Opiliones of the subantarctic islands of New Zealand. Pacific Insects Monograph 7: 58-115.

Hickman, V.V. (1957). Some Tasmanian harvestmen of the sub-order Palpatores. Papers and Proceedings of the Royal Society of Tasmania 91: 65-79.

Hunt, G.S. (1990). Taxonomic value of spiracle microstructure in the Megalopsalididae (Opiliones, Phalangioidea). Acta Zoologica Fennica 190: 187-194.

International Commission on Zoological Nomenclature (1999). International Code of Zoological Nomenclature, $4^{\text {th }}$ edition. International Trust for Zoological Nomenclature: London.

Kauri, H. (1954). Report from Professor T. Gislén's expedition to Australia in 1951-1952. 9. Harvestspiders from S. W. Australia. Lunds Universitets Ärsskrift. N. F. Avd. 2., 50(11): 1-10.

Linnaeus, C. (1758). Systema Naturæ per regna tria naturæ, secundum classes, ordines, genera, species, cum characteribus, differentiis, synonymis, locis. Tomus I. 
Editio decima, reformata. Holmiæ. 824 pp.

Martens, J. (1976). Genitalmorphologie, System und Phylogenie der Weberknechte (Arachnida: Opiliones). Entomologica Germanica 3: 51-68.

Nation, J.L. (1983). A new method using hexamethyldisilazane for preparation of soft insect tissues for scanning electron microscopy. Stain Technology 58: 347-351.

Sclater, P.L. 1866. Notes upon the American Caprimulgidae. Proceedings of the Zoological Society of London 1866: 123-45.

Šilhavý, V. (1970). Nouvelles recherches sur la famille des Neopilionidae Lawrence. Bulletin du Muséum National d'Histoire Naturelle series 2, 41 (Suppl. 1): 171-175.

Sørensen, W. 1886. Opiliones descripsit William Sorensen. In: L. Koch and E. von Keyserling, Die Arachniden
Australiens nach der natur beschrieben und abgebildet, vol. 2, pp. 53-86. Bauer und Raspe: Nürnberg.

Taylor, C.K. (2004). New Zealand harvestmen of the subfamily Megalopsalidinae (Opiliones: Monoscutidae) - the genus Pantopsalis. Tuhinga 15: $53-76$.

Taylor, C.K. (2008). A new species of Monoscutinae (Arachnida, Opiliones, Monoscutidae) from New Zealand, with a redescription of Monoscutum titirangiense. Journal of Arachnology 36: 176-179.

Manuscript received 19 December 2007; accepted 22 April 2008. 